\title{
Language Use by Staff Members in Saudi English Higher Education Departments: Beliefs and Gender Differences
}

\author{
Suliman Mohammed Nasser Alnasser ${ }^{1}$ \\ ${ }^{1}$ Department of English Language and Literature, College of Arts, King Saud University, Riyadh, Saudi Arabia \\ Correspondence: Suliman Mohammed Nasser Alnasser, Department of English Language and Literature, \\ College of Arts, King Saud University, P.O. Box 90096, Riyadh 11613, Saudi Arabia. E-mail: \\ smalnasser@ksu.edu.sa
}

Received: April 28, 2018

doi:10.5539/ies.v11n9p22
Accepted: July 30, $2018 \quad$ Online Published: August 28, 2018

URL: https://doi.org/10.5539/ies.v11n9p22

\begin{abstract}
Educational language policies in Saudi Arabia have attracted a great deal of attention in recent years. English departments in the country are comprised of male and female staff members who practise these language policies at departmental level and also outside the domain of the classroom and on a variety of occasions. There are several reasons for the use of English (a foreign language) alongside Arabic (the mother tongue) and these have an influence on the shape of current or future language policies. The effect of gender on the selection of particular reasons has not been investigated and this is the focus of the current paper. In the study referred to here, both quantitative (online survey) and qualitative (open-ended section) approaches to data collection were adopted. The context of the study was English departments in Saudi Arabian higher education establishments. The survey consisted of five items (statements) and two questions with open-ended sections. The data was collected from different regions of the country and included male $(n=67)$ and female $(n=143)$ staff members. The Chi-Square test of independence was administered to determine the significance of differences found between the two genders and only in one of the five items was a statistically significant difference found. It was, therefore, concluded that males and females in Saudi English departments share similar beliefs with regard to the use of language, with only slight differences between them. This paper discusses the implications of these findings as well as possible areas of investigation for future researchers.
\end{abstract}

Keywords: EFL, gender differences, language policy, language use, Saudi English departments

\section{Introduction}

In almost every Saudi higher education institution - universities and colleges - there are English departments. At present, there are over twenty-five English departments and the number is still growing. This is due to a rapidly increasing need for learning and specialising in English-related studies. In these departments, English (L2) is normally used on several occasions such as in meetings and for correspondence, whereas Arabic (L1) is used on many other occasions. Language policies (LP) concerning the use of the two languages are usually in operation in these departments, either intentionally or unintentionally. These policies will, in one way or another, govern the use of languages at department level, both inside and outside the classroom. Whatever the shape of these policies, they have usually emerged for good reasons, such as a need to practise the language, communicate with non-Arabic speakers and serve particular purposes. Research into Saudi LP is scarce and many gaps in the literature have yet to be filled. A small number of studies have investigated Saudi LP and addressed issues that concern education in general or Saudi language policies from perspectives other than that of higher education institutions (Alzahrani, 2017; Elyas \& Badawood, 2016; Barnawi \& Al-Hawsawi, 2016; Payne \& Almansour, 2014). Other studies have addressed LP adopted in the classroom by language instructors (Alshammari, 2011; Alsuhaibani, 2015; Sipra, 2013). Unlike these studies, the focus of the current study was more specific in that it was concerned with LP being used within Saudi institutions and outside the domain of the classroom. Differences in the beliefs of male and female members of staff regarding language use-English and Arabic - at department level were investigated, an area that has not previously been addressed in the literature. 


\section{Literature Review}

\subsection{Beliefs about Language}

Beliefs in an educational context have been an area of interest to several researchers as they can have an effect on certain practices, either personally or institutionally. Beliefs have been defined as "psychologically held understandings, premises, or propositions about the world that are felt to be true" (Richardson, 1996, p. 102). Schoenfeld (1983) argues that an individual and his/her intellectual performance are stimulated through essential aspects: metacognition, belief system and social cognitions. Beliefs are also seen to have an impact on several personal skills such as learning, thinking, reasoning and problem solving (Kardash \& Scholes, 1996). Ozdemir (2013) argues that the influence of beliefs can extend to cognition, attitudes and views. At a community level, beliefs of individuals can evolve to become an ideology that is shared by many other members of the community (Ricento, 2013). Here, Van Dijk (1998, p. 8) has defines ideology as "the shared framework(s) of social beliefs that organize and coordinate the social interpretations and practices of groups and their members". Furthermore, Blommaert (2006) speculates that in an educational setting ideology can significantly influence the formation of learning, practices, identities and systems. It can be speculated here that beliefs held by an individual can guide the process of developing any set of governing rules in a community and that they can explain why current practices are the way they are. With regard to this study, it is assumed that the belief of staff members can have an effect on the shape of LP in an English department and that they can explain the nature of certain policies.

\subsection{Language Policy}

Language policies around the world are important in that they govern language use within communities. This explains the enormous number of decisions on LP being made globally. The need for LP stems from the fact that they can, for example, govern the use of more than one language within a community. An example of this is found in South Africa where more than ten languages are spoken, including English, Afrikaans and indigenous languages. Given this situation, the South African government needs to have clear policies as to which language or languages are to be used for education, public signage and areas of this sort.

Cooper (1989, p. 45) describes language policy as the "deliberate efforts to influence the behaviour of others with respect to the acquisition, structure, or functional allocation of their language codes". Keplan and Baldauf (1997, p. xi) further explain that "the exercise of language planning leads to, or is directed by, the promulgation of a language policy by government (or other authoritative body or person). A language policy is a body of ideas, laws, regulations, rules and practices intended to achieve the planned language change in the societies, group or system". It is suggested that there are three components of LP, namely: the practice of a language within a community, intended changes in the current practice and existing beliefs and ideologies about current language practice (Spolsky, 2004).

Globally, LP can be classified under three main categories which relate to the way they were formed, methods used and goals set for them and the way they are documented (Johnson, 2013). The first category-the way LP are formed - refers to whether policies were made by higher governmental bodies and passed down to lower communities to be put into practice, also referred to as top-down processes. Alternatively, they may have been made by smaller communities who have direct exposure to or practice with the languages and passed on to higher authorities for approval, which are referred to as bottom-up polices (Johnson, 2013). The former are seen as of great importance to the lower communities and therefore abiding by them is an issue to be considered. In the case of the latter - the bottom-up policies - any violation of the regulations does not necessarily raise concerns to their makers unless stated otherwise. Additionally, these policies can be practised in one small community but will not necessarily become accepted by an adjacent, similar community such as two English (Note 1) departments in the same city or region. Relating this to the present study, the phenomenon investigated here seems to be a bottom-up process that has emerged at department level and not something passed down by the education ministry.

The second category - means and goals - is divided into two sub-categories: those announced to the public, or 'overt' policies and those concealed from the public or 'covert' policies (Johnson, 2013; Schiffman, 2010; Shohamy, 2006). Depending on the nature of polices and their intended goals, policy makers decide whether they should be covert or overt. For example, a country with several indigenous languages might consider adopting a covert policy if they decide to make one language the official language of communication, as otherwise speakers of other languages might be put out.

The third category of LP concerns whether or not policies are documented and that if they are, the way in which they are documented indicates their level of formality (Johnson, 2013; Schiffman, 1996). It is clear that LP usually need be documented in a written or spoken manner explicitly to ensure that in they are regarded as official and abided by. On the other hand, however, if an LP has emerged naturally and spontaneously in an informal manner, 
perhaps made by a group of people in a small community and without being approved officially, they are seen to be implicit and non-formal polices. Violating these policies or even changing them does not necessarily raise much concern as they are flexible in nature. To this end, LP at a departmental level are normally considered implicit and non-official since members from different genders can have different beliefs in terms of language use and they may have not been documented.

\subsection{Saudi Context and the English Language}

Prior to a discussion of the status of the English language in a Saudi context, it is important to discuss governmental language planning approaches. According to Ferguson (1968), Haugen (1983) and Hornberger (2006), acquisition and status planning are the two main types of planning. Bright (1992) described them as the 'dimensions' of language planning. In brief, acquisition planning refers to all decisions made to promote the teaching and learning of a language, while status planning refers to how a language is treated in a particular context. Questions to be asked would include whether it is a formal language, whether one is permitted to use it in formal governmental channels and whether it is used in the media (c.f. Wardhaugh \& Fuller, 2015).

The official language of Saudi Arabia is Arabic, the language of its tribes for centuries and the language of the Muslim holy book (the Quran). In this regard, several researchers have described Arabic as 'the holy language' (Fishman, 2002; Liddicoat: 2012; Payne \& Almansour, 2014). Some countries may be tempted to adopt a religious aspect to any planning concerning such holy language as special attention is paid to it. This would also be in order to promote acquisition levels and status of the language (Liddicoat: 2012). In the Saudi constitution there are no references to any languages other than Arabic, yet there are obvious practical indications that English has been accorded a high status by the government. Acquisition planning concerning the English language on the part of the Saudi government can be seen in several instances. For example, the government has indicated a strong desire to promote the teaching and learning of English even at the early stages of education. The language is now taught in compulsory sessions starting from fourth elementary to undergraduate level (Alasmari \& Khan, 2014). Saudi Arabia also employs the other type of language planning - status planning - to promote the English language at a national level. The government has its own intentions with regard to enhancing the status of English in the country and any observer from outside or inside the country can verify this very easily. Saudi official websites, such as ministry websites which are directed solely at Saudi citizens, are commonly offered in both Arabic and English. Furthermore, Saudi Arabia's formal television channels, radio stations, application forms, driving licences and public signs are normally provided in both languages.

The government has nurtured English within several domains across the country, but has not promoted any other foreign languages. Foreigners in Saudi Arabic who speak languages other than Arabic or English outnumber by far those who speak English, yet English is the only foreign language that is taught and accorded importance in the country. Considering the political and economic influence of the West on the rest of the world, which has led to English becoming a lingua franca, it is not surprising that the Saudi government is paying special attention to English (c.f. Alzahrani, 2017). Around the world, individuals and governments have been using English as a shared language for communication, the aforementioned lingua franca, for some time (c.f. Firth, 1996; Seidlhofer, 2005). Given the high status accordance of English by the Saudi government and the status of English internationally, it can be speculated that beliefs of members of the Saudi community can be influenced in terms of their language use.

\subsubsection{Saudi Arabia as an EFL Context}

In order for any language to be acquired or learned, there has to be sufficient exposure to it (Bisson et al., 2014; Paradis, 2010). Many foreign and second language speakers work on maintaining their linguistic competency by practising the language whenever possible. In EFL contexts, such as that in Saudi Arabia, opportunities to practise English can be quite limited. Wu and Wu (2008) and Parker et al. (1995) state that in such a context English is not a living language that provides its speakers with sufficient exposure for language development and that such a context is not likely to offer authentic situations for language practice. For adults in particular, it is very important that there are sufficient situations that provide opportunities for authentic language practice since this will help them to acquire an adequate grasp of the language (Pèrez-Leroux et al., 2004; Spolsky, 1989). Chang and Shu (2000) add that authentic situations can create an encouraging environment for language development. The nature of the Saudi context is quite similar to the scenario depicted by W. Wu and P. Wu (2008) and Parker et al. (1995) in that opportunities for English speakers to practise the language are likely to be limited to a few small domains such as in classrooms, with work friends who do not speak Arabic and occasionally in up-market restaurants. As a reaction to living in such a context, some staff members in English departments in Saudi Arabia may use the language at department level more often and in any possible situation. It is their reasons for using English that are 
investigated in this study and the above discussion can be linked to the findings of the study.

\subsection{Gender Differences}

At departmental level, LP can be designed to clarify particular reasons for and the particular occasions on which a language or languages are spoken. At this level the LP are being practised by males and females for specific reasons, so it is important to establish the possibility of there being gender-related differences for these reasons. From a general perspective, the literature includes numerous studies on gender-related differences. In psychology, for example, the relationship between gender and verbal performance and cognition has been investigated and the findings suggest that there are significant differences between males and females (Bacon \& Finnemann, 1992). In an educational context significant differences have been found between the two genders. For example, it has been found that males and females tend to use different learning strategies and that those differences were found to be significant (Oxford, 1989). Furthermore, another study revealed that there are significant differences between the two genders in terms of their beliefs with regard to using learning strategies (Yilmaz, 2010). Turning to language use, a number of studies suggest the existence of differences between the two genders. For example, each gender is likely to use different interactive patters from the other (Tannen, 1995), can show different degrees of speech engagement (Herring, 2000) and males exhibit more assertive attitudes in their speech (Herring, 2000; Leaper \& Ayres, 2007). Unlike most of these studies, Bernat and Lloyd's (2007) did not find significant differences between males and females in terms of their beliefs about language learning, concluding that the two genders had similar beliefs. In brief, with regard to the existence of gender-related differences in the disciplines of education and language use, the findings reported in the literature suggest the existence of significant differences. They also suggest, however, that these differences may not exist in certain situations or contexts. The significance of the current study stems from the fact that it attempts to investigate whether or not gender differences exist amongst members of staff and their language use at departmental level.

\section{Method}

For the current study, both qualitative and quantitative methods of data collection were employed. The context of the study was English departments in higher education establishments in Saudi Arabia. Data were gathered from different regions and from members of staff of different genders affiliated to those departments. The researcher has worked in Saudi English departments for many years (Note 2) and verified from fellow members of staff from different departments in the country that English departments do, in general, practise LP. These policies specify - overtly or covertly - the various occasions on which English is to be used, indicating that it is permitted to use Arabic (L1) on other occasions. The purpose of this study was not to investigate what language policies were being practised in these departments, but rather to investigate whether or not there are gender-related differences among staff members in terms of their beliefs about the use of English and Arabic at department level and outside the domain of the classroom. The following research question was therefore developed for the study: How different are the beliefs of male and female staff in Saudi English departments regarding the use of English and Arabic at departmental level?

\subsection{Online Survey}

The study employed an online survey using the Google online survey system, publicised via social media and email. After announcing the survey, two weeks were allowed to accept responses. The survey included an introductory section that explained the scope and purpose of the study. This was followed by a background section that enquired about the gender and expertise of the respondent, region where the department was located and academic rank. The survey also included a section containing five items or 'statements', for which a five-point Likert scale was used - strongly agree, agree, not sure, disagree and strongly disagree. The five items measured responses related to reasons for having the current LP. Responding to these sections was mandatory for all participants. The final section, which was optional, was open-ended and included two questions. One enquired about reasons for using English and situations in which English was used at departmental level, while the other enquired about reasons for using Arabic and situations in which Arabic was used at this level.

\subsection{Participants}

The target for this study was staff working in the English departments of Saudi higher education institutions. A total of 210 responses from members of staff_ -67 males and 143 females-were received. They were of different ranks such as TA, lecturers, assistant professors, associate professors and full professors and were affiliated to different English departments from the main regions of the country. They also had different specialisms such as applied linguistics, theoretical linguistics, literature and translation. 


\section{Results}

In this section the results of the survey are presented and analysed. Since the key thrust of the study was gender differences, the overall results are not the focus here. The number of responses by each gender to each point in the scale used, in addition to the overall percentages were, however, used for analysis and are examined here in detail. Furthermore, a statistical test was conducted for the five items to investigate the significance of differences between male and female participants.

\subsection{The Survey Items}

(1) Since I am affiliated to an English department, I should use English most of the time within the department.

Table 1. Using English because of affiliation with an English department

\begin{tabular}{|c|c|c|c|c|}
\hline \multirow{2}{*}{ Value } & \multicolumn{2}{|c|}{ Frequency } & \multicolumn{2}{|c|}{ Percent } \\
\hline & Male & Female & Male & Female \\
\hline Strongly agree & 37 & 104 & 55.22 & 72.73 \\
\hline Agree & 21 & 32 & 31.34 & 22.38 \\
\hline Not sure & 8 & 6 & 11.94 & 4.20 \\
\hline Disagree & 1 & 1 & 1.49 & 0.70 \\
\hline Strongly disagree & 0 & 0 & 0 & 0 \\
\hline Total & 67 & 143 & 100 & 100 \\
\hline Grand total & \multicolumn{2}{|c|}{210} & & \\
\hline
\end{tabular}

Table 2. Chi-Square test

\begin{tabular}{lccc}
\hline & Value & df & $\begin{array}{c}\text { Asymptotic } \\
\text { Significance } \\
(2 \text {-sided })\end{array}$ \\
\hline $\begin{array}{l}\text { Pearson Chi-Square } \\
\text { N of Valid Cases }\end{array}$ & 7.941 & 3 & .047 \\
\hline
\end{tabular}

The participants were asked whether or not being a member of an English department was a reason for using the English language most of the time. In general, the majority of participants $(n=194)$ either strongly agreed or just agreed with the statement. Fourteen participants were not sure and two of them disagreed with the statement. A thorough examination of the data revealed that $55.22 \%$ of male and $72.73 \%$ of female participants strongly agreed with this notion, a difference of $17.51 \%$ between the two groups in favour of the female participants (see Table 1 above). Some $31.34 \%$ of males and $22.38 \%$ of females said they agreed, making a difference of $8.96 \%$ between the two groups in favour of male participants. Those who were not sure comprised $11.94 \%$ of males and $4.20 \%$ of females and there was a difference of $7.74 \%$ between the two groups in favour of male participants. Only $1.49 \%$ of males and $0.70 \%$ of females disagreed with the statement, making a difference of $0.79 \%$ between the two groups in favour of male participants.

The Chi-Square test of independence was run on the data to investigate whether or not gender differences observed in the responses were statistically significant. The results revealed that the differences were statistically significant, at a $p$ value of 0.047 (see Table 2 above). A further examination of the data suggested that differences related to the 'strongly agree' responses contributed the most to significant gender-related differences. The data also suggest that males were slightly more hesitant than females in expressing their beliefs with regard to this notion.

(2) I use English in order to maintain my own proficiency levels. 
Table 3. Using English to maintain language proficiency

\begin{tabular}{|c|c|c|c|c|}
\hline \multirow[b]{2}{*}{ Value } & \multicolumn{2}{|c|}{ Frequency } & \multicolumn{2}{|c|}{ Percent } \\
\hline & Male & Female & Male & Female \\
\hline Strongly agree & 34 & 89 & 50.64 & 62.24 \\
\hline Agree & 19 & 35 & 28.36 & 24.48 \\
\hline Not sure & 9 & 15 & 13.43 & 10.49 \\
\hline Disagree & 3 & 3 & 4.48 & 2.10 \\
\hline Strongly disagree & 2 & 1 & 2.99 & 0.70 \\
\hline Total & 67 & 143 & 100 & 100 \\
\hline Grand total & \multicolumn{2}{|c|}{210} & & \\
\hline
\end{tabular}

Table 4. Chi-Square test

\begin{tabular}{lccc}
\hline & Value & df & $\begin{array}{c}\text { Asymptotic } \\
\text { Significance } \\
\text { (2-sided) }\end{array}$ \\
\hline $\begin{array}{l}\text { Pearson Chi-Square } \\
\text { N of Valid Cases }\end{array}$ & 4.215 & 4 & .378 \\
\hline
\end{tabular}

With regard to whether or not staff members use English in order to maintain linguistic proficiency, the majority of participants $(n=177)$ either strongly agreed or just agreed with the statement. Twenty-four participants were unsure about the statement, only six disagreed and only three participants strongly disagreed with the statement. After examining the data thoroughly, it was found that $50.64 \%$ of male and $62.24 \%$ of female participants strongly agreed with the notion, making a difference of $11.60 \%$ between the two groups in favour of female participants (see Table 3 above). Some $28.36 \%$ of males and $24.48 \%$ of females agreed with the notion, making a difference of $3.88 \%$ between the two groups in favour of male participants. Those who were not sure made up $13.43 \%$ of male and $10.49 \%$ of female participants, making a difference of $2.94 \%$ between the two groups in favour of male participants. Furthermore, $4.48 \%$ of males and $2.10 \%$ of females disagreed with the statement, making a difference of $2.38 \%$ between the two groups in favour of male participants. Finally, $2.99 \%$ of the males and $0.70 \%$ of females strongly disagreed with the statement, making a difference of $2.29 \%$ between the two groups in favour of male participants.

The Chi-Square test was run on the data to investigate the significance of the gender differences observed, but the results showed no statistically significant differences $(p=0.378)$ (see Table 4 above). It can be said, however, that females hold slightly stronger beliefs than males, particularly in their selection of the 'strongly agree' response.

(3) Departmental language policies should consider the existing debate on using L1 in L2 educational contexts

Table 5. ELPs influenced by L1 \& L2 research

\begin{tabular}{|c|c|c|c|c|}
\hline \multirow[b]{2}{*}{ Value } & \multicolumn{2}{|c|}{ Frequency } & \multicolumn{2}{|c|}{ Percent } \\
\hline & Male & Female & Male & Female \\
\hline Strongly agree & 10 & 36 & 14.92 & 25.17 \\
\hline Agree & 24 & 47 & 35.82 & 32.87 \\
\hline Not sure & 25 & 52 & 37.31 & 36.36 \\
\hline Disagree & 5 & 7 & 7.46 & 4.90 \\
\hline Strongly disagree & 3 & 1 & 4.48 & 0.70 \\
\hline Total & 67 & 143 & 100 & 100 \\
\hline Grand total & \multicolumn{2}{|c|}{210} & & \\
\hline
\end{tabular}

Table 6. Chi-Square test

\begin{tabular}{lccc}
\hline & Value & df & $\begin{array}{c}\text { Asymptotic } \\
\text { Significance } \\
\text { (2-sided) }\end{array}$ \\
\hline $\begin{array}{l}\text { Pearson Chi-Square } \\
\text { N of Valid Cases }\end{array}$ & 6.263 & 4 & .180 \\
\hline
\end{tabular}


This question was designed to find out whether staff members believed that the way LP are shaped in English departments should take into account the debate in the literature on the use of L1 in L2 contexts. The majority of the participants $(n=117)$ either strongly agreed or agreed with the statement. In addition, seventy-seven participants were unsure about the statement and twelve disagreed with it. It was seen that only four participants strongly disagreed with the statement. After examining the data thoroughly, it was found that $14.92 \%$ of male and $25.17 \%$ of female participants strongly agreed with the notion, making a difference of $10.25 \%$ between the two groups in favour of female participants (see Table 5 above). Some $35.82 \%$ of the males and $32.87 \%$ of the females agreed with the notion, making a difference of $2.95 \%$ between the two groups in favour of male participants. Those who were not sure made up $37.31 \%$ of male and $36.36 \%$ of female respondents, making a difference of $0.95 \%$ between the two groups in favour of male participants. Furthermore, $7.46 \%$ of the males and $4.90 \%$ of females disagreed with the statement, making a difference of $2.56 \%$ between the two groups in favour of male participants. It was seen that $4.48 \%$ of males and $0.70 \%$ of females strongly disagreed with the statement, making a difference of $3.78 \%$ between the two groups in favour of male participants.

The Chi-Square test was run on the data to investigate the significance of the gender differences observed in the responses, but the results were statistically insignificant $(p=0.180)$ (see Table 6 above). It can be said, however, that females demonstrated slightly stronger beliefs than males, particularly in their selection of the 'strongly agree' 'response. Interestingly, hesitation to agree or disagree with this statement was observed among a considerable proportion of both males and females.

(4) In some circumstances, the use of Arabic should be allowed (e.g., to save time)

Table 7. Allowing the use of Arabic

\begin{tabular}{|c|c|c|c|c|}
\hline \multirow{2}{*}{$\frac{F}{\text { Value }}$} & \multicolumn{2}{|c|}{ Frequency } & \multicolumn{2}{|c|}{ Percent } \\
\hline & Male & Female & Male & Female \\
\hline Strongly agree & 12 & 22 & 17.91 & 15.38 \\
\hline Agree & 35 & 59 & 52.24 & 41.26 \\
\hline Not sure & 10 & 36 & 14.93 & 25.17 \\
\hline Disagree & 4 & 17 & 5.97 & 11.89 \\
\hline Strongly disagree & 6 & 9 & 8.96 & 6.29 \\
\hline Total & 67 & 143 & 100 & 100 \\
\hline Grand total & \multicolumn{2}{|c|}{210} & & \\
\hline
\end{tabular}

Table 8. Chi-Square test

\begin{tabular}{lccc}
\hline & Value & df & $\begin{array}{c}\text { Asymptotic } \\
\text { Significance } \\
\text { (2-sided) }\end{array}$ \\
\hline $\begin{array}{l}\text { Pearson Chi-Square } \\
\text { N of Valid Cases }\end{array}$ & 5.647 & 4 & .227 \\
\hline
\end{tabular}

The majority of participants $(n=128)$ either strongly agreed or agreed with the statement that Arabic should be used in some circumstances. Additionally, some forty-six participants were unsure about the statement and twenty-one disagreed with it. Finally, fifteen participants strongly disagreed with the statement. A thorough examination of the data revealed that $17.91 \%$ of male and $15.38 \%$ of female participants strongly agreed with the notion, making a difference of $2.53 \%$ between the two groups in favour of the male participants (see Table 7 above). A total of $52.24 \%$ of males and $41.26 \%$ of females agreed with the notion, making a difference of $10.98 \%$ between the two groups in favour of the male participants. Those who were not sure totaled $14.93 \%$ of males and $25.17 \%$ of females, making a difference of $10.24 \%$ between the two groups in favour of the female participants. Furthermore, $5.97 \%$ of males and $11.89 \%$ of females disagreed with the statement, making a difference of $5.92 \%$ between the two groups in favour of the female participants. Finally, $8.96 \%$ of males and $6.29 \%$ of females strongly disagreed with the statement, making a difference of $2.67 \%$ between the two groups in favour of the male participants.

The Chi-Square test was run on the data to investigate the significance of the gender differences observed in the responses and no statistically significant differences were found $(p=0.227)$ (see Table 8 above). It can be said, however, that females appeared more hesitant about supporting the statement than males and more females than 
males disagreed with the statement.

(5) English language policies outside the classroom should be limited to teacher-student communication.

Table 9. Limiting LP to communication with students

\begin{tabular}{|c|c|c|c|c|}
\hline \multirow{2}{*}{$\frac{F}{\text { Value }}$} & \multicolumn{2}{|c|}{ Frequency } & \multicolumn{2}{|c|}{ Percent } \\
\hline & Male & Female & Male & Female \\
\hline Strongly agree & 10 & 25 & 14.92 & 17.48 \\
\hline Agree & 21 & 41 & 31.34 & 28.67 \\
\hline Not sure & 13 & 37 & 19.40 & 25.87 \\
\hline Disagree & 13 & 25 & 19.40 & 17.48 \\
\hline Strongly disagree & 10 & 15 & 14.93 & 10.49 \\
\hline Total & 67 & 143 & 100 & 100 \\
\hline Grand total & \multicolumn{2}{|c|}{210} & & \\
\hline
\end{tabular}

Table 10. Chi-Square test

\begin{tabular}{lccc}
\hline & Value & df & $\begin{array}{c}\text { Asymptotic } \\
\text { Significance } \\
\text { (2-sided) }\end{array}$ \\
\hline $\begin{array}{l}\text { Pearson Chi-Square } \\
\text { N of Valid Cases }\end{array}$ & 1.939 & 4 & .747 \\
\hline
\end{tabular}

This statement asked participants whether they thought that LP should be limited to when they were communicating with students. A large proportion of participants $(n=97)$ either strongly agreed or just agreed with the statement. In addition, fifty participants reported their hesitation to support the statement and thirty-eight of them disagreed with it. Finally, some twenty-five participants strongly disagreed with the statement. A thorough examination of the data revealed that $14.92 \%$ of male and $17.48 \%$ of female participants strongly agreed with the notion, making a difference of $2.56 \%$ between the two groups in favour of the female participants (see Table 9 above). A total of $31.34 \%$ of males and $28.67 \%$ of females said they agreed with the notion, making a difference of $2.67 \%$ between the two groups in favour of the male participants. Turning to those who were not sure, they made up a total of $19.40 \%$ of males and $25.87 \%$ of females. There was a difference of $6.47 \%$ between the two groups in favour of the female participants. Furthermore, $19.40 \%$ of males and $17.48 \%$ of females disagreed with the statement, making a difference of $1.92 \%$ between the two groups in favour of the male participants. Finally, a total of $14.93 \%$ of males and $10.49 \%$ of females strongly disagreed with the statement, making a difference of $4.44 \%$ between the two groups in favour of the male participants.

The Chi-Square test was run on the data in order to investigate the significance of the gender-related differences observed in the responses and the test revealed no statistically significant differences $(p=0.747)$ (see Table 10 above). It can be said, however, that females showed slightly more hesitation to support the statement than males. It was also observed that the majority of males $(53.73 \%)$ and females $(53.84 \%)$ either hesitated to support the statement or disagreed with it.

\subsection{Open-Ended Section}

The participants were given two open-ended questions investigating reasons for use and instances when the English and Arabic languages should be used. Unlike the five items discussed above, answering these questions was not mandatory.

(1) For what reasons and in what situations do you think English should be used in your department and outside the domain of the classroom?

Overall, some fifty-five participants expressed their thoughts on the use of English (L2) around English departments. In detail, seventeen (25.33\%) male and thirty-eight (26.6\%) female participants provided comments. These comments (reasons) were then classified under five categories (see Table 11 below). 
Table 11. Reasons for using English language (L2) at department level

\begin{tabular}{|c|c|c|c|c|c|}
\hline \multirow{2}{*}{ No. } & \multirow{2}{*}{ Reason (category) } & \multicolumn{2}{|c|}{ Male responses ${ }^{*}$} & \multicolumn{2}{|c|}{ Female responses $^{* *}$} \\
\hline & & Count & Percentage & Count & Percentage \\
\hline 1 & Because English is a lingua franca & 4 & 5.96 & 15 & 10.5 \\
\hline 2 & Because of affiliation with English departments & 1 & 1.49 & 6 & 4.2 \\
\hline 3 & Because a high status is accorded to English & 1 & 1.49 & 2 & 1.4 \\
\hline 4 & For linguistic proficiency reasons & 11 & 16.39 & 13 & 9.1 \\
\hline 5 & Just personal preference & 0 & 0 & 2 & 1.4 \\
\hline & Total & 17 & 25.33 & 38 & 26.6 \\
\hline
\end{tabular}

*: Statistics here are pertaining to the whole male participants; **: Statistics here are pertaining to the whole female participants.

Table 11 above shows that both females and males opted to use English at departmental level for several reasons. The most commonly reported reason was that it was a common language among other non-Arabic speaking staff as English is a lingua franca. In that regard, fifteen female participants highlighted this reason, but only four males gave the same response. Therefore, it can be said that females showed more concern for non-Arabic speaking members of staff than males. The other main reason that was commonly reported was that English was used for reasons associated with linguistic proficiency. This was reported by eleven males and thirteen females and related to either their own proficiency or that of the students.

Other reasons reported were related to the participants and their affiliation with English departments, the status of English and pure personal preference.

(2) For what reasons and in what situations do you think English should be used in your department and outside the domain of the classroom?

Overall, a total of eighty-one participants expressed their feelings with regard to reasons for using Arabic (L1) in around English departments. In detail, some twenty-one (31.29\%) male and sixty (42\%) female participants provided comments. These comments (reasons) were then classified under seven categories (see Table 12 below).

Table 12. Reasons for using Arabic language (L1) at department level

\begin{tabular}{llcccc}
\hline \multirow{2}{*}{ No. } & Reasons (categories) & \multicolumn{2}{c}{ Male responses } & \multicolumn{2}{c}{ Female responses } \\
\cline { 3 - 6 } & & Count & Percentage & Count & Percentage \\
\hline 1 & To avoid communication breakdown & 1 & 1.49 & 4 & 2.8 \\
2 & For administrative purposes & 3 & 4.47 & 0 & 0 \\
3 & In the presence of non-English speaking personnel or civilians & 8 & 11.92 & 20 & 14 \\
4 & When there is no need to use English & 0 & 0 & 7 & 4.9 \\
5 & On sensitive occasions & 1 & 1.49 & 3 & 2.1 \\
6 & In informal situations & 1 & 1.49 & 8 & 5.6 \\
7 & To ensure proper delivery of meaning & 7 & 10.43 & 18 & 12.6 \\
\hline Total & & 21 & 31.29 & 60 & 42 \\
\hline
\end{tabular}

The data presented in Table 12 above suggests that both genders had a preference for using Arabic (L1) in Saudi English departments and outside the classroom. The reasons they gave were diverse. The most commonly reported reason was that Arabic should be used when a non-English speaking member of staff was present. It was observed that similar proportions of each group were concerned about this issue, totaling $11.92 \%$ of males and $14 \%$ of females. Another, similar, commonly reported reason by both genders was that Arabic can be very useful for conveying meaning. This was reported by $10.43 \%$ of males and $12.6 \%$ of females. For example, it was reported that Arabic is useful for explaining difficult words and concepts, translating new terminology and for general queries. Additionally, both male and female participants gave other reasons: Arabic should be used in order to avoid communication breakdown, on sensitive occasions and in informal settings. Three males reported that Arabic was used for administrative purposes, but none of the females stated this. In addition, seven females reported that Arabic should be used when there is no need to use English — among Arabic speakers — but none of the males stated this. 


\section{Discussion}

Overall, the results from the five items suggest that both genders in Saudi English departments hold similar thoughts about the reasons for using English, with the exception of one item. It was found that there was a statistically significant difference between males and females in their ideas about the frequency of using English at department level because of their affiliation to English departments. The significance was traced to the responses of strongly agree which were among males $55.22 \%$ and females $72.73 \%$. This suggests that females have a stronger belief that they use the language because of their affiliation to an English department than males. It is, therefore, possible to say that females may be keener to endow English departments with an identity or image that reflects their sole mission as a department concerned with the English language. It is also possible that they want to become exemplars for their students, either to encourage them to use the language more often or to allow more practice.

Interestingly, both genders reported similar ideas with regard to using English in order to maintain linguistic proficiency, with females appearing to hold slightly stronger beliefs. Even though academics in Saudi Arabia can be very likely to be fluent in English, they still feel the need to practise the language more often.

As mentioned earlier, the Saudi EFL context is seen as one that may not offer many opportunities to practise English outside the domain of the department. Additionally, the department is made up of a community - a staff — of fluent speakers of English that may not exist in other domains in the country. It is possible that both male and female participants in our study realised that a lack of exposure to the language in the Saudi EFL context may lead to deterioration in their linguistic competency and that, therefore, there is a need for more practice.

This study investigated the relationship between the L1 and L2 debate and department LP. In this regard, there has been an ongoing debate for decades on the use of L1 in L2 contexts and the arguments presented in the literature have been inconclusive (see Cook, 2008). The subject has been a topic of heated controversy on Saudi forums and in the media for many years and has attracted the attention of several Saudi researchers (c.f. Alsuhaibani, 2015) affiliated to Saudi English departments. In other words, it is clear that Saudi English departments are well acquainted with this particular debate. In addition, the debate has been taught at university level for several years as an integral part of second language acquisition courses. It is possible that the debate might have influenced the beliefs of members of staff who took part in our study about the way in which English is used at departmental level. In fact, half of the male and female participants reported their support for the notion that it was necessary to consider the aforementioned debate when designing LP at departmental level. On the other hand, a considerable proportion of males $(37.31 \%)$ and females $(36.36 \%)$ were hesitant about supporting the notion and another, smaller, proportion completely rejected the idea. This suggests that in their view it may not be appropriate to involve the debate in the formation of LP and that it should probably be limited to classroom LP and discussions with students. In support of this view, it can be said that the main import of the debate was related to learning second and foreign languages and that members of staff are expected not to 'learn English', but to maintain their existing linguistic proficiency levels as discussed in the previous paragraph).

With regard to allowing the use of Arabic at departmental level, the majority of both males and females were in support of this concept and the differences found between the two groups were not statistically significant. The findings from the open-ended section did not show any significant gender-related differences in participant responses either. The results obtained from this section do, however, present several situations in which it is reasonable to use Arabic. The two most obvious examples are when in the presence of non-English speaking personnel and in order to ensure the efficient delivery of meaning or messages. With regard to the first situation, in Saudi Arabian English departments, administrative staff will not necessarily speak English. Occasionally they may attend committee meetings to take minutes and will communicate with other members of staff either face to face or via email. Interestingly, several of the male participants held the view that the use of Arabic should be allowed at departmental level for administrative purposes, such as responding to a formal letter or sending requests to other departments within the university or similar institutions. None of the female participants appeared to hold this view, however, possibly because it is normally males who hold the leading positions such as head of a committee, unit or department. With regard to the second situation and to ensure the efficient delivery of meaning or messages, this can be linked to the earlier discussion in which it was suggested that the debate over the use of L1 in an L2 context should be considered when developing LP, in that the supporters of the debate believe that L1 is an essential tool for conveying meaning. One of the other instances when it is permissible to use Arabic was reported by females only. This is when there is no need to use English, perhaps when all individuals present speak Arabic. This was reported by only seven female participants, which does not represent the whole female sample. It may seem logical not to use English all the time in order to avoid prioritising L2 over the mother tongue, or simply because it can be more comfortable to speak in one's native language. 
Both genders were inquired whether or not LP should be limited to staff-student communication and the findings revealed similar beliefs. Almost half the males and females agreed that LP should not cover staff-staff communication, suggesting a desire for flexibility in their communication with one another and possibly rejecting any governing rules that demand the use of a particular language on particular occasions. On the other hand, another half of the respondents were either unsure about or disagreed with the statement. This indicates their desire to have LP that includes staff-staff communication as well. Analysis of the findings from the open-ended section provides some justification for these views. As pointed out earlier, English is a means of communication with non-Arabic speaking speakers of English because it is a lingua franca. An English department is likely to employ members of staff who do not speak Arabic_-British, Americans or Indians - but these members of staff are still involved in decision making and participate in committees and department councils. If Arabic-speaking members of staff use Arabic for communication in these situations, it would be considered disrespectful to the non-Arabic speakers present. An additional point in support of this argument is that most of the participants reported using English in order to maintain their linguistic proficiency, which was discussed earlier in this section.

The participants were asked about reasons for using English (L1) and Arabic (L2) and the occasions on which each language should be used at departmental level. With regard to English, several occasions and reasons were reported and these were classified into five categories (see Table 11 above). A similar proportion of males $(25.33 \%)$ and females $(26.6 \%)$ reported their beliefs in this regard. With regard to the use of Arabic, a higher percentage of females responded to the statement than males (males responding totaled $31.29 \%$ and females $42 \%$ ) and the responses were classified into seven categories (see Table 12 above). This suggests that females may be more likely to use Arabic at departmental level than males. Overall, it can be said that both genders share similar beliefs with regard to occasions on which Arabic and English should be used and the reasons for using them. They were, however, in more agreement about the use of English than about the use of Arabic.

In Saudi English departments, English as a foreign language is spoken at departmental level and outside the classroom. The way in which English is used forms the essence of LP that can be explicit, implicit, written, spoken, formal or informal. Investigating gender-related beliefs about the reasons and instances in which the English (L2) and Arabic (L1) languages are used can provide us with insights into how LP in higher educational institutions are designed. In other words, they help to explain how existing policies were shaped and provide those who have an interest in working on developing LP with points of consideration from two different perspectives obtained from different genders. Furthermore, the investigation reveals how similar or different the beliefs of male and female members of staff are, which can provide policymakers with insights into the influence of their thinking relating to the use of the two languages on their actions and behaviour. Generally speaking, although the literature suggests that there are gender-related differences in the beliefs of male and female members of staff in both educational and non-educational contexts, the findings of the current study suggest that in Saudi English departmental contexts there are no significant differences. This may be because both genders are well-educated and affiliated to respected institutions that comprise elite members of society.

\section{Conclusion}

The study investigated gender-related differences in the beliefs of members of staff in Saudi English departments. It was found that there were no significant differences, with the exception of one item, where females appeared to have stronger beliefs than males. The findings of the study are of importance for Saudi English departments that intend either to design or revise their current language policies. Future studies are encouraged to investigate the relationship between the ideas of members of staff relating to the use of English and Arabic and their linguistic proficiency (whether fluent, native-like or average speakers). Also, it is recommended that the relationship between belief and academic rank, subject specialty and age be investigated. Finally, the data obtained from the open-ended section of the survey indicates that there is a possible relationship between the status of English and Arabic languages in wider society and their use at departmental level. It was not possible to speculate further on this matter as there was insufficient evidence. Therefore, it is recommended that this area to also be investigated in the future. Finally, it is recommended that future researchers employ interviews as a research tool in order to allow even deeper and more insightful findings to be obtained.

\section{References}

Alasmari, A., \& Khan, S. (2014). World Englishes in the EFL teaching in Saudi Arabia. Arab World English Journal, 5(1), 316-325.

Alshammari, M. (2011) The use of the mother tongue in Saudi EFL classrooms. Journal of International Education Research, 7(4), 95-102. https://doi.org/10.19030/jier.v7i4.6055

Alsuhaibani, Y. (2015). The perceptions and practice of L1 Arabic in Saudi university English classrooms (PhD 
thesis, University of Newcastle).

Alzahrani, A. (2017). Markets and language policy in Saudi Arabia: How the English language can contribute to the success of the Saudi Vision 2030. International Journal of English Language and Linguistic Research, $5(6), 11-12$.

Bacon, S. M. C., \& Finnemann, M. D. (1992). Sex differences in self-reported beliefs about language learning and authentic oral and written input. Language Learning, 42(4), 471-495. https://doi.org/10.1111/j.1467-1770.1992.tb01041.x

Barnawi, O., \& Al-Hawsawi, S. (2016). English language education policy in the Kingdom of Saudi Arabia: Current trends, issues and challenges. In R. Kirkpatrick (Ed.), English language education policy in the Middle East and North Africa (pp. 223-234). Switzerland: Springer International Publishing.

Bernat, E., \& Lloyd, R. (2007). Exploring the gender effect on EFL learners' beliefs about language learning. Australian Journal of Educational \& Developmental Psychology, 7, 79-91.

Bisson, M. J., van Heuven, W. J. B., Conklin, K., \& Tunney, R. J. (2014). The role of repeated exposure to multimodal input in incidental acquisition of foreign language vocabulary. Language Learning, 64(4), 855-877. https://doi.org/10.1111/lang.12085

Blommaert, J. (2006). Language policy and national identity. In T. Ricento (Ed.), An introduction to language policy: Theory and Method (pp. 238-54). Malden, MA: Blackwell.

Bright, W. (1992). Language policy. International Encyclopedia of Linguistics, 4, 310-311.

Chang, C. P., \& Shu, M. Z. (2000). The experiment research for English teaching with small class of junior high school (The Ministry of Education, The 2000 Academic Year Research Project of Taiwan High School Technician Conference).

Cook, V. J. (2008). Second language learning and language teaching (4th ed.). London: Routledge.

Cooper, R. L. (1989). Language planning and social change. Cambridge, England: Cambridge University Press.

Elyas, T., \& Badawood, O. (2016). English language educational policy in Saudi Arabia post 21st century: Enacted curriculum, identity, and modernisation: A critical discourse analysis approach. FIRE: Forum for International Research in Education, 3(3), 70-81.

Ferguson, C. A. (1968). Language development. In J. A. Fishman, C. A. Ferguson, \& J. Dasgupta (Eds.), Language problems of developing nations (pp. 29-97). New York; London: Wiley.

Firth, A. (1996). The discursive accomplishment of normality on "lingua franca" English and conversation analysis. Journal of Pragmatics, 26, 237-59. https://doi.org/10.1016/0378-2166(96)00014-8

Fishman, J. A. (2002). Holy languages' in the context of societal bilingualism. Contributions to the Sociology of Language, 87, 15-24. https://doi.org/10.1515/9783110852004.15

Haugen, E. (1983). The implementation of corpus planning: theory and practice. In J. Cobarrubias, \& J. A. Fishman (Eds.), Progress in language planning: International perspectives (pp. 269-290). New York: Mouton Publishers.

Herring, S. C., (2000). Gender differences in CMC: Findings and implications. Computer Professionals for Social Responsibility Journal, 18(1).

Hornberger, N. (2006). Frameworks and models in language policy and planning. In T. M. Ricento (Ed.), An introduction to language policy: Theory and method (pp. 24-41). MA: Blackwell Pub.

Johnson, D. C. (2013). Language policy. Hampshire: Macmillan, UK. https://doi.org/10.1057/9781137316202

Kaplan, R. B., \& Baldauf, R. B. (1997). Language planning: From practice to theory. Clevedon: Multilingual Matters Ltd.

Kardash, D. A., \& Scholes, R. J. (1996). Effects of pre-existing beliefs, epistemological beliefs, and need for cognition on interpretation of controversial issues. Journal of Educational Psychology, 88(2), 260-271. https://doi.org/10.1037/0022-0663.88.2.260

Leaper, C., \& Ayres, M., (2007). A Meta-analytic review of gender variations in adults' language use: Talkativeness, affiliative speech, and assertive speech. Personality and Social Psychology Review, 11(4), 328-363. https://doi.org/10.1177/1088868307302221

Liddicoat, A. J. (2012). Language planning as an element of religious practice. Current Issues in Language 
Planning, 13(2), 121-144. https://doi.org/10.1080/14664208.2012.686437

Milligan, L. (2016). Insider-outsider-inbetweener? Researcher positioning, participative methods and cross cultural educational research. Compare: A Journal of Comparative and International Education, 46(2), 235-250. https://doi.org/10.1080/03057925.2014.928510

Oxford, R. (1989). Use of language learning strategies: A synthesis of studies with implications for strategy training. System, 17, 235-247. https://doi.org/10.1016/0346-251X(89)90036-5

Ozdemir, G. (2013). Erasumus exchange students' beliefs about language learning. Procedia Social and Behavioral Sciences, 70, 686-690. https://doi.org/10.1016/j.sbspro.2013.01.109

Paradis, J. (2010). Bilingual children's acquisition of English verb morphology: Effects of language exposure, structure complexity, and task type. Language Learning, 60(3), 651-680. https://doi.org/10.1111/j.1467-9922.2010.00567.x

Parker, J. E., Heitzman, S. M., Fjerstad, A. M., Babbs, L. M., \& Cohen, A. D. (1995). Exploring the role of foreign language in immersion education. In D. Highland, P. W. Lee, J. Milcham, \& R. R. Weber (Eds.), Second language acquisition theory and pedagogy (pp. 235-253). Mahwah. NJ: Lawrence Erlbaum Associates.

Payne, M., \& Almansour, M. (2014). Foreign language planning in Saudi Arabia: Beyond English. Current Issues in Language Planning, 15(3), 327-342. https://doi.org/10.1080/14664208.2014.915461

Pèrez-Leroux, A. T., Munn, A., Schmitt, C., \& DeIrish, M. (2004). Learning definite determiners: Genericity and definiteness in English and Spanish. Boston University, Conference on Language Development, 28, Proceedings Supplement. Retrieved from http://www.bu.edu/linguistics/APPLIED/BUCLD/supp.html

Ricento, T. (2013). Language policy, ideology and attitudes in English-dominant countries. In R. Bayley, R. Cameron, \& C. Lucas (Eds.), The Oxford handbook of sociolinguistics (pp. 525-543). Oxford: Oxford University Press. https://doi.org/10.1093/oxfordhb/9780199744084.013.0026

Richardson, V. (1996). The role of attitudes and beliefs in learning to teach. In J. Sikula, T. J. Buttery, \& E. Guyton (Eds.), Handbook of research on teacher education (pp. 102-109). New York, NY: Macmillan.

Schiffman, H. F. (1996). Linguistic culture and language policy. London: Routledge. https://doi.org/10.4324/9780203273487

Schiffman, H. F. (2010). South and Southeast Asia. In J. A. Fishman, \& O. Garcia (Eds.), Handbook of language and ethnic identity: Disciplinary and regional perspectives (pp. 452-469). Oxford University Press.

Schoenfeld, A. H. (1983). Beyond the purely cognitive: Belief systems, social cognitions, and metacognitions as driving forces in intellectual performance. Cognitive Science, 7, 329-363. https://doi.org/10.1207/s15516709 $\operatorname{cog} 0704 \_3$

Seidlhofer, B. (2005). English as a lingua franca. ELT Journal, 59(4), 339-341. https://doi.org/10.1093/elt/cci064

Shohamy, E. (2006). Language policy: Hidden agendas and new approaches. London and New York: Routledge. https://doi.org/10.4324/9780203387962

Sipra, A. (2013). Contribution of bilingualism in language teaching. Canadian Centre of Science and Education Journal, 6(1), 56-66. https://doi.org/10.5539/elt.v6n1p56

Spolsky, B. (1989). Consider for second language learning. Oxford: Oxford University Press.

Spolsky, B. (2004). Language policy. Cambridge: Cambridge University Press.

Tannen, D. (1995). Gender and discourse. Oxford: Oxford University Press.

Van Dijk, T. A. (1998). Ideology: A multidisciplinary approach. London: Sage.

Wardhaugh, R., \& Fuller, J. M. (2015). An introduction to sociolinguistics (7th ed.). Chichester: Wiley Blackwell.

Wu, W., \& Wu, P. (2008). Creating an authentic EFL learning environment to enhance student motivation to study English. Asian EFL Journal, 10(4), 211-222, Conference Proceedings.

Yilmaz, C. (2010). The relationship between language learning strategies, gender, proficiency and self-efficacy beliefs: A study of ELT learners in Turkey. Procedia Social and Behavioral Sciences, 2, 682-687. https://doi.org/10.1016/j.sbspro.2010.03.084 


\section{Notes}

Note 1. An English department is seen as a community that practices LP.

Note 2. A research report from within the source of the phenomenon has been referred to as an 'insider report' and is seen as a data collection method by some researchers (Milligan, 2016). In this study, it was only used to establish the existence of LP at Saudi department level in order to provide a rationale for investigating the reasons for the use of L1 and L2, based on which LPs were formed.

\section{Copyrights}

Copyright for this article is retained by the author(s), with first publication rights granted to the journal.

This is an open-access article distributed under the terms and conditions of the Creative Commons Attribution license (http://creativecommons.org/licenses/by/4.0/). 